\title{
Effect of EAF Slag Temperature and Composition on its Electrical Conductivity
}

\author{
Raafat FARAHAT, ${ }^{1 * *}$ Mamdouh EISSA, ${ }^{2)}$ Gamal MEGAHED, ${ }^{1)}$ Ayman FATHY,1) Soha ABDEL-GAWAD ${ }^{3)}$ and \\ Mohamed Saada EL-DEAB ${ }^{3)}$
}

1) Al Ezz Flat Steel, Suez, 43511 Egypt.

2) Central Metallurgical R\&D Institute (CMRDI), Cairo, 11731 Egypt.

3) Cairo University; Faculty of science, Cairo, 12613 Egypt.

(Received on July 16, 2018; accepted on October 17, 2018)

\begin{abstract}
Slag practice is one of the most important factors in molten steel production. Physical and chemical properties of slag determine the efficiency of the production process. Slag electrical conductivity is the second effective parameter in slag practice after viscosity. During current study, effect of temperature, $\mathrm{FeO}, \mathrm{CaO}, \mathrm{SiO}_{2}$ content and basicity ratio $\mathrm{B} 2$ on slag's electrical conductivity was studied experimentally. It was found that, electrical conductivity increases with increasing temperature, \% $\mathrm{FeO}, \% \mathrm{CaO}$ and basicity B2. On the other hand electrical conductivity was decreased with increasing $\mathrm{SiO}_{2}$ content. Specific conductance and electric conductivity index for slag main constituents were also estimated.
\end{abstract}

KEY WORDS: slag; slag practice; basicity; electrical conductivity.

\section{Introduction}

Slag plays a very important role in hot metal production and refining. The properties of slag have great effect on energy, refractory and electrode consumption as well as steel quality and material yield. Around $25 \%$ of worldwide crude steel is produced by using electric arc furnace. In electric steelmaking, the second highest cost after raw material is the energy. Silicates is the basis of electric arc furnace slags and their physical properties are very dependent on the silicate structure developed in the molten slag. The dependence of property on structure is in the hierarchy, ${ }^{1)}$ viscosity $(\eta)>$ electrical conductivity $(\kappa)$ and thermal conductivity $(\mathrm{k})>$ thermal expansion coefficient $(\alpha)>$ density $(\rho)>$ surface tension $(\gamma)>\mathrm{Cp}$ and enthalpy. One of the main factors affect the performance of slag in electric arc furnace is its electrical conductivity $(\kappa) .{ }^{1)}$ In addition, electrical conductivity of slag plays an important role in the electrochemical reaction between metal and slag. $\left.{ }^{2}\right)$

Electrical conductivity of materials is the ability to transfer electrical charges by positive or negative carriers (cations, anions) under the influence of an external electric field. ${ }^{3)}$ Electrical conductivity is dependent upon the number of ions available, it follows that the electrical conductivity of $\kappa \mathrm{Na}_{2} \mathrm{O}>\kappa \mathrm{CaO}$. The electrical conductivity is also dependent upon the mobility of the cations; thus it would be expected that the conductivity would be greater for smaller cations; this is valid for $\mathrm{Li}, \mathrm{Na}$, and $\mathrm{K}$ ions, but the reverse trend can be seen with $\mathrm{Ba}, \mathrm{Ca}$, and $\mathrm{Mg}$. This is probably due

\footnotetext{
* Corresponding author: E-mail: r.farahat@ezzsteel.com DOI: https://doi.org/10.2355/isijinternational.ISIJINT-2018-507
}

to the effects of increased polarization with decreasing ionic radius that could also affect the cationic mobility. ${ }^{1)}$

\subsection{Factors Influencing Electrical Conductivity}

The electrical conductivity involves the movement of cations under the influence of an applied field. In this case, the polymeric silicate network hinders the movement of the cations. Thus the factors affecting the electrical conductivity $(\kappa)$ are:

1. Chemical composition, charge and size of the cations. ${ }^{1)}$ The highest electrical conductivity has a slag rich in $\mathrm{FeO}$ and $\mathrm{MnO}$ - except of ion conductivity they also have electron conductivity. Electron conductivity of the slag can be explained by the presence in them of the metal cations in both valency 2 and $3\left(\mathrm{Fe}^{3+}+\right.$ $\left.\mathrm{e}=\mathrm{Fe}^{2+}\right)^{3-5)}$ with Standard Potential $\mathrm{E}^{\circ}=0.77$ volt. The electric conductivity of the slags containing large amount of $\mathrm{FeO}, \mathrm{MnO}, \mathrm{TiO}_{2}$ are usually very high, but the current efficiency and the ionic migration rate are lower. ${ }^{2)}$

2. The polymeric network (as represented by $Q)^{1,6)}$

$$
\begin{aligned}
& Q=4-\left(\frac{N B O}{T}\right) \\
& \left(\frac{\mathrm{NBO}}{\mathrm{T}}\right)=\frac{2\left(\mathrm{XCaO}+\mathrm{XNa}_{2} \mathrm{O}+\mathrm{X} \mathrm{Al}_{2} \mathrm{O}_{3}\right)}{\left(\mathrm{XSiO}_{2}+2 \mathrm{XAl}_{2} \mathrm{O}_{3}\right)}
\end{aligned}
$$

Where $\mathrm{Q}$ is the degree of polymerization, $\mathrm{NBO}$ is the non-bridging $\mathrm{O}, \mathrm{T}$ is the tetragonal $\mathrm{O}$ and $\mathrm{X}$ is the mole fraction.

3. Temperature, conductivity increases with increasing 
temperature due to gradually loosens of the structure that hinders the movement of cations by the silicate network. ${ }^{1,6)}$ The value of electrical conductivity decreases rapidly to one hundredth when slag solidifies. ${ }^{3)}$

Table 1 shows the electrical conductivity of some pure oxides in the liquid phase at the temperature just above melting point of each one. ${ }^{7)}$ The low conductance of $\mathrm{SiO}_{2}$ is characteristic of network-forming compounds. $\mathrm{FeO}$ exhibits the highest conductance. The specific electrical conductivity measurement can provide us with basic information about depolymerization of molten slag and thus the mobility of ions as well as other features such as viscosity and solidification process. ${ }^{8)}$ So, electrical conductivity presents very significant information about the molten slag.

The objective of the current paper is to study the correlations of electrical conductivity of electric arc furnace slag to its chemical composition and temperature.

\section{Experimental}

In the current study, experimental work has been carried out at laboratories of EZZ steel factories located at Suez city, around $130 \mathrm{Km}$ from Cairo. Electrical conductivity of $\mathrm{CaO}-\mathrm{SiO}_{2}-\mathrm{FeO}$ slag system has been studied in this paper. $\mathrm{Al}_{2} \mathrm{O}_{3}$ and $\mathrm{MgO}$ was kept within the technically preferred concentration throughout the study. Two-electrode alternative current impedance method was used. The experiments were carried out in the normal atmospheric air to simulate the actual industrial process.

\subsection{Effect of Temperature on Slag Electrical Conduc- tivity}

Slag was heated up to $1660^{\circ} \mathrm{C}$ in a zirconia boat by using laboratory resistance furnace. The sample was kept for 10 minutes inside the furnace for the slag to be melted completely. The sample size for each experiment was 15 g. By the end of 10 minutes time, the boat containing the completely melted slag sample was taken out and placed in another heated larger boat to reduce the cooling rate. The electrical conductivity of molten slag and temperature were measured from that temperature up to cooling. Also electrical conductivity of some trials was measured inside the furnace at lower temperatures. The circuit used to measure the conductivity is shown in Fig. 1.

\subsection{Effect of Chemical Composition on Slag Electrical Conductivity}

Number of slag samples was collected from EZZ Steel 185 tonne $\mathrm{AC}$ electric arc furnace with different $\mathrm{FeO}, \mathrm{CaO}$ and $\mathrm{SiO}_{2}$ concentration. From each one a serious of samples

Table 1. Electrical conductivity of pure oxides.

\begin{tabular}{ccc}
\hline Oxide & $\mathrm{T}^{\circ} \mathrm{C}$ & $\kappa, 1 /$ ohm-cm \\
\hline $\mathrm{SiO}_{2}$ & 1710 & $10^{-5}$ \\
$\mathrm{Al}_{2} \mathrm{O}_{3}$ & 2050 & 15 \\
$\mathrm{CaO}$ & 2580 & 40 \\
$\mathrm{FeO}$ & 1370 & 122 \\
$\mathrm{MgO}$ & 2800 & 35 \\
\hline
\end{tabular}

was modified. In each series all studied oxides was kept constant except one to be studied. Slag modification was done by using pure $\mathrm{FeO}, \mathrm{SiO}_{2}$ and $\mathrm{CaO}$. First series was modified to have different concentration of $\mathrm{FeO}$ while other constituents kept constant. Second series was modified to have different concentration of $\mathrm{CaO}$ while other constituents kept constant. Third series was modified to have different concentration of $\mathrm{SiO}_{2}$ while other constituents kept constant. The results of two $\mathrm{CaO}$ and $\mathrm{SiO}_{2}$ series were used to study the effect of basicity $\mathrm{B}_{2}$. Slag basicity $\mathrm{B}_{2}$ is the ratio of $\% \mathrm{CaO} / \% \mathrm{SiO}_{2}$.

\section{Results and Discussion}

\subsection{Effect of Temperature on Slag Electrical Conduc- tivity}

One industrial slag sample selected to be used for determination of electrical conductivity at different temperatures. Chemical composition of used sample is shown in Table 2. The logarithmic values of measured electrical conductivity against temperature are shown in Fig. 2. It was found that,

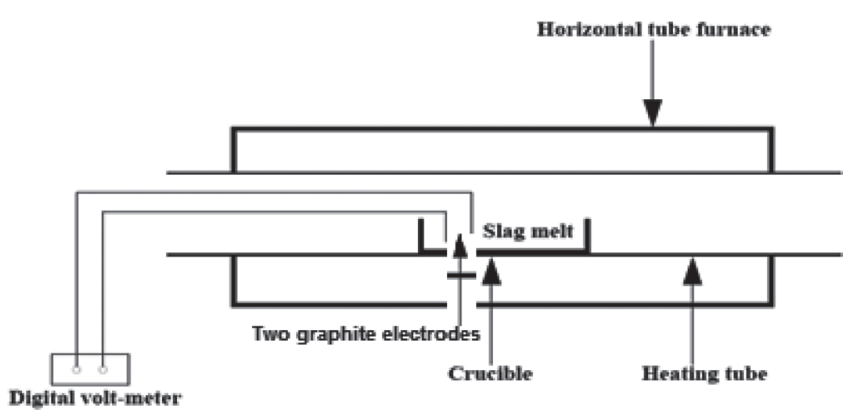

Fig. 1. Electric circuit used for measuring slag electrical conductivity.

Table 2. Chemical composition of slag sample used for temperature study.

\begin{tabular}{cccccc}
\hline$\% \mathrm{CaO}$ & $\% \mathrm{SiO}_{2}$ & $\% \mathrm{FeO}$ & $\% \mathrm{MgO}$ & $\% \mathrm{Al}_{2} \mathrm{O}_{3}$ & $\% \mathrm{MnO}$ \\
\hline 35.3 & 18.1 & 25 & 8.8 & 5.38 & 1.58 \\
\hline
\end{tabular}

Log conductivity, S/m

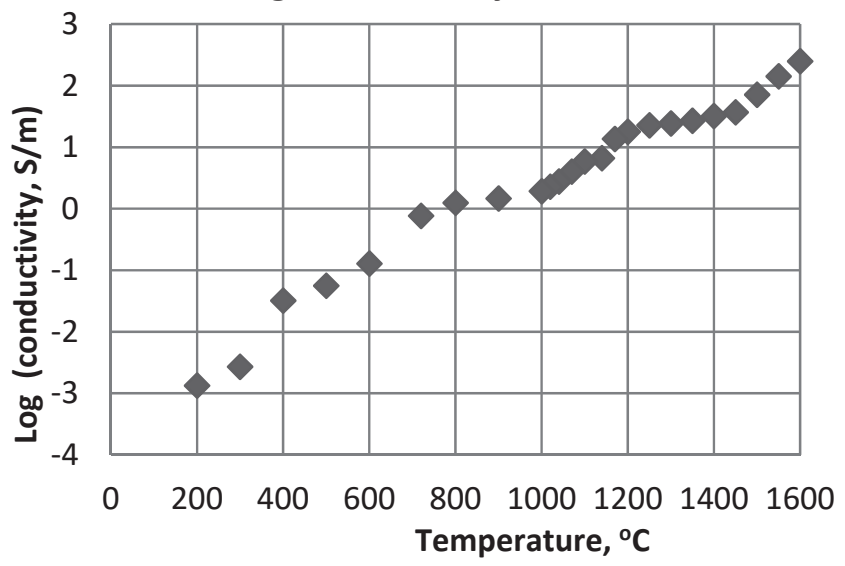

Fig. 2. Relation between slag electrical conductivity and temperature. 
electrical conductivity increases exponentially as the temperature increases. The rate was very low at temperature less than $1200^{\circ} \mathrm{C}$ as shown in Fig. 2. Then it increases at very high rate after $1400^{\circ} \mathrm{C}$ which is nearly the melting point of $\mathrm{FeO}$, the principle fluxing oxide. This can be explained by the looseness of the silicate structure and increase of ion mobility with temperature. The tested slag sample was completely nonconductive below $135^{\circ} \mathrm{C}$. The obtained results are matched with the data reported by Jixiang et al. ${ }^{5)}$ The maximum applied temperature was $1600^{\circ} \mathrm{C}$ which is less than the liquidus temperature of investigated slag as shown in Figs. 3 and 4. During investigating the system, sum of $\% \mathrm{CaO}$ and $\% \mathrm{MgO}$ taken as $\mathrm{CaO}$ since they have nearly the same behavior while $\mathrm{Al}_{2} \mathrm{O}_{3}$ was ignored since it is relatively low concentration. At that temperature the liquidus composition was liquid, $2 \mathrm{CaO}-\mathrm{SiO}_{2}$ and $3 \mathrm{CaO}-\mathrm{SiO}_{2} \cdot{ }^{9,11)}$ As the temperature decreases the percentage of solid phase particles increased till reaching to all solid at around $1480^{\circ} \mathrm{C}$. Accordingly, during the current study all the measurements

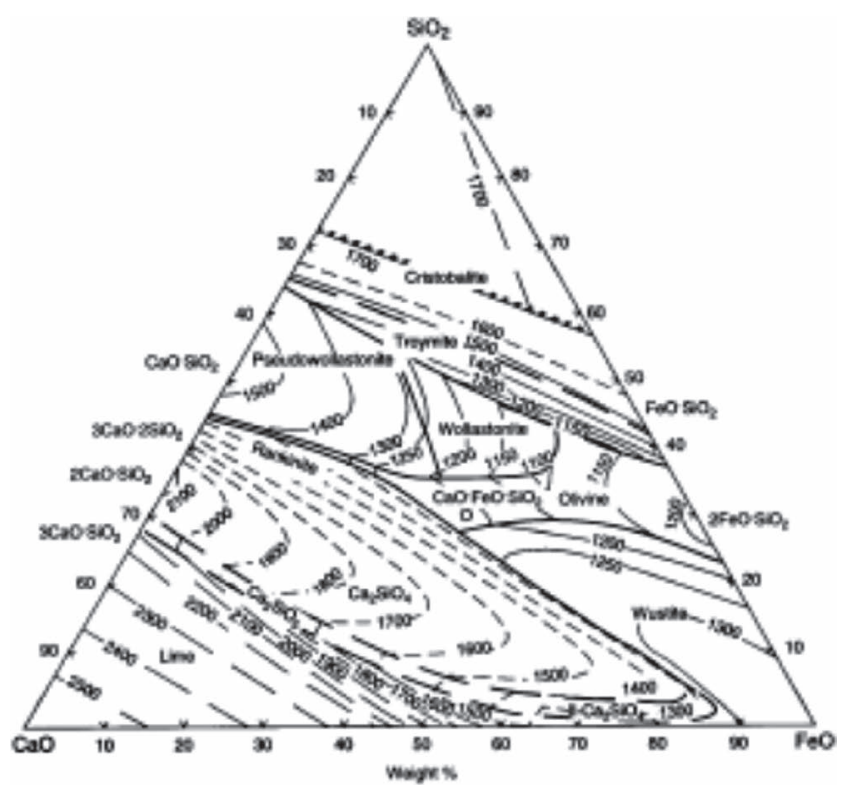

Fig. 3. Phase relation in the system $\mathrm{CaO}-\mathrm{SiO} 2-\mathrm{FeO}$ in contact with metallic iron.

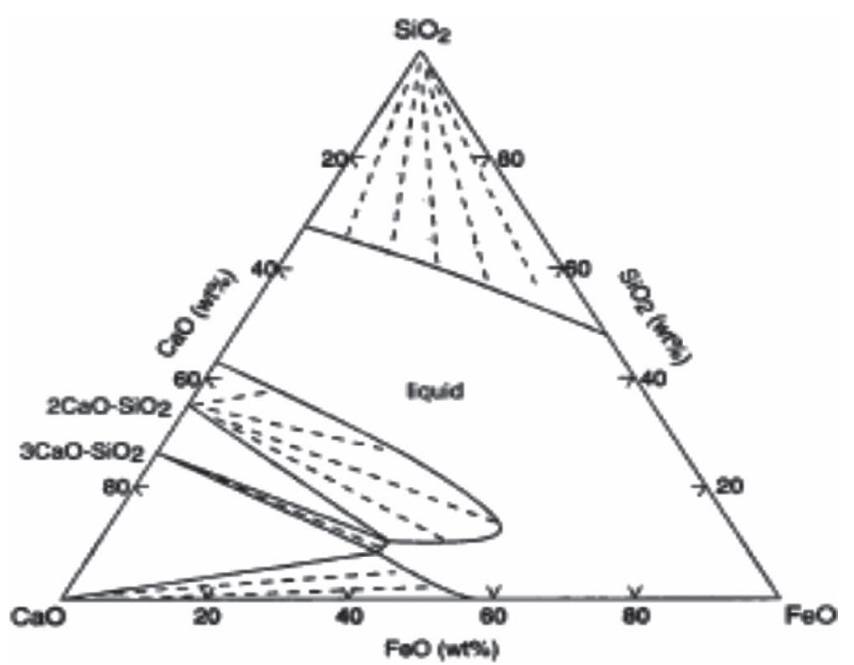

Fig. 4. The $1600^{\circ} \mathrm{C}$ isothermal section through the system $\mathrm{CaO}-$ $\mathrm{SiO} 2-\mathrm{FeO}$ were carried out for a molten slag which contains a liquid phase coexisted with another solid phase.

\subsection{Effect of FeO Content on Slag Electrical Conduc- tivity}

One industrial slag sample containing lower $\mathrm{FeO}$ content was selected to determine the effect of $\mathrm{FeO}$ content on its electrical conductivity. Chemistry of selected sample is depicted in Table 3. The electrical conductivity of the selected sample and the modified samples prepared from it to get higher FeO content is shown in Fig. 5. It was found that, the electrical conductivity increases at high rate as the $\mathrm{FeO}$ increases. The electrical conductivity increased five times when the concentration of $\mathrm{FeO}$ was duplicated. $\mathrm{FeO}$ has the lowest melting point among slag constituents; accordingly its effect on electrical conductivity is very deep. Also $\mathrm{FeO}$ exhibit both ionic and electronic conductivity. This can be proved by the XRD pattern, Fig. 6, for one of the tested samples which shows presence of both $\mathrm{Fe}^{3+}$ and $\mathrm{Fe}^{2+}$. The obtained results are matched with the results obtained by Lijun Wang for the same $\mathrm{FeO}$ content and basicity. ${ }^{10)}$ At the working temperature of $1600^{\circ} \mathrm{C}$ and $20 \%$ $\mathrm{FeO}$, the liquidus composition was liquid, $2 \mathrm{CaO}-\mathrm{SiO}_{2}$ and $3 \mathrm{CaO}-\mathrm{SiO}_{2}{ }^{9}{ }^{911)}$ As the $\% \mathrm{FeO}$ increases the solid particles decreased till $38 \% \mathrm{FeO}$ which is the maximum investigated concentration.

\subsection{Effect of $\mathrm{SiO}_{2}$ Content on Slag Electrical Conduc- tivity}

One industrial slag sample containing lower $\mathrm{SiO}_{2}$ was selected to determine the effect of silica content on its electrical conductivity. Chemistry of selected sample is depicted in Table 4. Electrical conductivity of the selected sample and the modified samples prepared from it to get higher $\mathrm{SiO}_{2}$ content is shown in Fig. 7. The highest conduction was registered at lowest $\mathrm{SiO}_{2}$ content then the conductivity decreased as the $\mathrm{SiO}_{2}$ increased. Increasing $\mathrm{SiO}_{2}$ enhances the silicate network that hinders the movement of ions and reduces the electrical conductivity. Also increasing $\mathrm{SiO}_{2}$ content increases the viscosity and accordingly reduces the conductivity. At the working temperature of $1600{ }^{\circ} \mathrm{C}$ and $13.7 \% \mathrm{SiO}_{2}$, the liquidus composition was liquid, $2 \mathrm{CaO}-$ $\mathrm{SiO}_{2}$ and $3 \mathrm{CaO}-\mathrm{SiO}_{2}{ }^{9}{ }^{9,11)}$ As the $\% \mathrm{SiO}_{2}$ increases the solid

Table 3. Chemical composition of slag sample used for $\mathrm{FeO}$ study.

\begin{tabular}{cccccc}
\hline$\% \mathrm{CaO}$ & $\% \mathrm{SiO}_{2}$ & $\% \mathrm{FeO}$ & $\% \mathrm{MgO}$ & $\% \mathrm{Al}_{2} \mathrm{O}_{3}$ & $\% \mathrm{MnO}$ \\
\hline 40 & 19.7 & 20 & 5.7 & 6.7 & 1.8
\end{tabular}

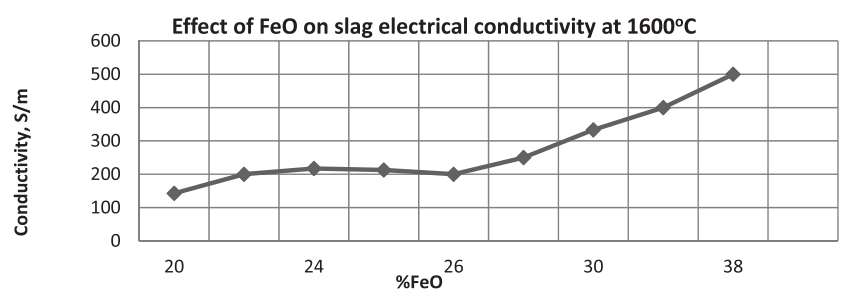

Fig. 5. Relation between slag electrical conductivity and $\mathrm{FeO}$ content at $1600^{\circ} \mathrm{C}$. 


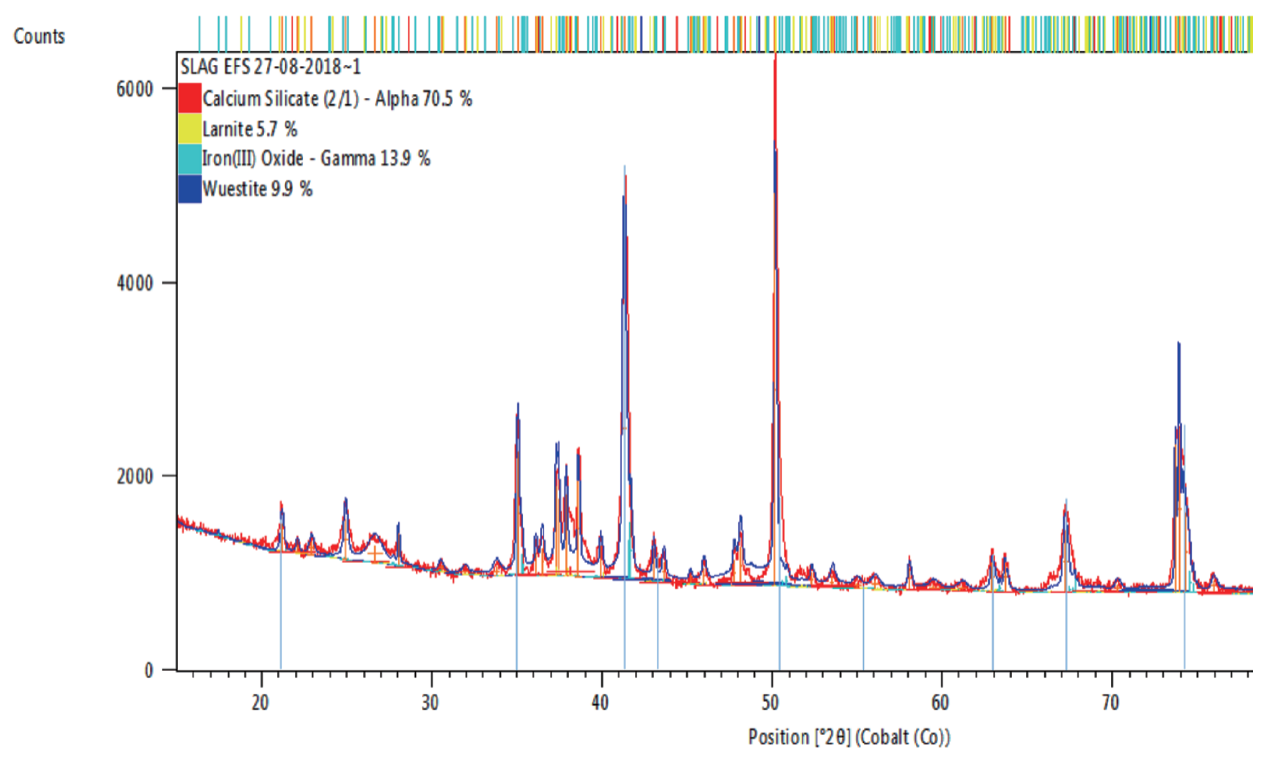

Fig. 6. EAF slag X-ray diffraction pattern. (Online version in color.)

Table 4. Chemical composition of slag sample used for $\mathrm{SiO}_{2}$ study.

\begin{tabular}{cccccc}
\hline$\% \mathrm{CaO}$ & $\% \mathrm{SiO}_{2}$ & $\% \mathrm{FeO}$ & $\% \mathrm{MgO}$ & $\% \mathrm{Al}_{2} \mathrm{O}_{3}$ & $\% \mathrm{MnO}$ \\
\hline 33.1 & 13.7 & 38.1 & 6.91 & 5.5 & 0.9 \\
\hline
\end{tabular}

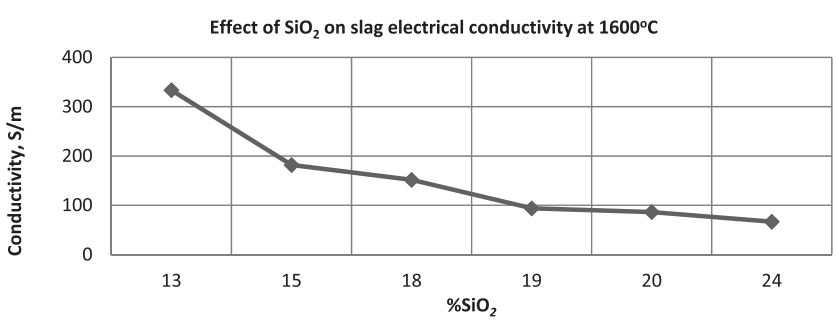

Fig. 7. Relation between slag electrical conductivity and $\mathrm{SiO}_{2}$ content at $1600^{\circ} \mathrm{C}$.

particles increased.

\subsection{Effect of $\mathrm{CaO}$ Content on Slag Electrical Conduc- tivity}

One industrial slag sample containing lower $\mathrm{CaO}$ was selected to determine the effect of $\mathrm{CaO}$ content on its electrical conductivity. Chemistry of selected sample is depicted in Table 5. The electrical conductivity of the selected sample and the modified samples prepared from it to get higher $\mathrm{CaO}$ content is shown in Fig. 8. Electrical conductivity was low at lower $\mathrm{CaO}$ and increased as the concentration of $\mathrm{CaO}$ increased. $\mathrm{CaO}$ break the silicate network, reduce the slag viscosity, increase the ion mobility and accordingly increase the electrical conductivity. At the working temperature of $1600{ }^{\circ} \mathrm{C}$ and $30 \% \mathrm{CaO}$, the liquidus composition was liquid, $2 \mathrm{CaO}-\mathrm{SiO}_{2}$ and $3 \mathrm{CaO}-\mathrm{SiO}_{2}{ }^{\left.{ }^{9}{ }^{9}\right)}$ As the $\% \mathrm{CaO}$ increases the solid particles increased.

\subsection{Effect of Basicity B2 on Slag Electrical Conductiv- ity}

The electrical conductivity results of selected and modified samples for $\mathrm{CaO}$ and $\mathrm{SiO}_{2}$ were used to study the effect
Table 5. Chemical composition of slag sample used for $\mathrm{CaO}$ study.

\begin{tabular}{cccccc}
\hline$\% \mathrm{CaO}$ & $\% \mathrm{SiO}_{2}$ & $\% \mathrm{FeO}$ & $\% \mathrm{MgO}$ & $\% \mathrm{Al}_{2} \mathrm{O}_{3}$ & $\% \mathrm{MnO}$ \\
\hline 30 & 15 & 30.4 & 7.7 & 6.1 & 1.2 \\
\hline
\end{tabular}

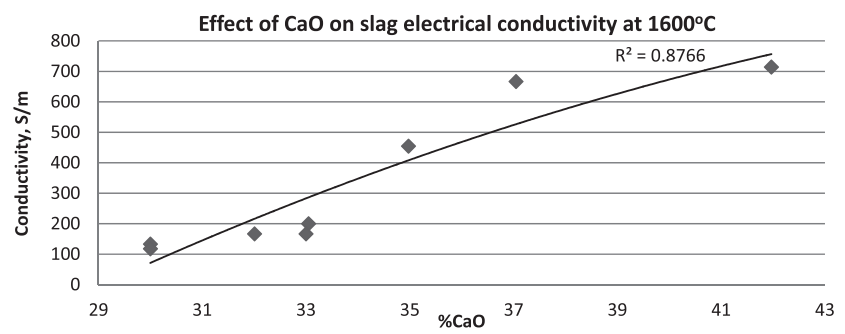

Fig. 8. Relation between slag electrical conductivity and $\mathrm{CaO}$ content at $1600^{\circ} \mathrm{C}$.

of basicity $\mathrm{B}_{2}$. It was found that electrical conductivity increases with increasing basicity. This can be explained by breaking of the silicate network that hinders the movement of cations and also reducing the slag viscosity as per Eq. (3). The obtained results are depicted in Fig. 9.

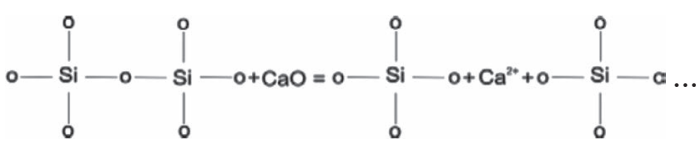

It was reported that, slag electrical conductivity is a function of optical basicity. ${ }^{11)}$ Wanli et al. ${ }^{12)}$ studied the electrical conductivity of $\mathrm{CaO}-\mathrm{SiO}_{2}-\mathrm{Al}_{2} \mathrm{O}_{3}-\mathrm{MgO}$ system as well as the viscosity and found the relation:

$$
\ln \eta=-0.041-1.14 \ln \kappa
$$

So, there is a direct relation between slag electrical conductivity with its viscosity and degree of polymerization. Although Eq. (4) is applied for a slag system that is different from investigated one but both contain $\mathrm{CaO}$ and $\mathrm{SiO}_{2}$ which is the main constituents affecting viscosity and degree of polymerization.

Sensitivity of slag electrical conductivity per percent of 


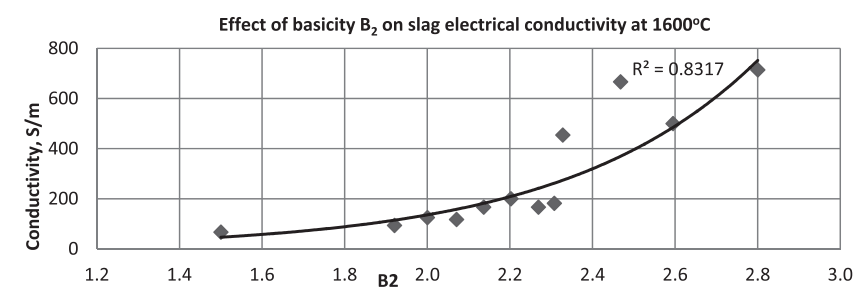

Fig. 9. Relation between slag electrical conductivity and basicityat $1600^{\circ} \mathrm{C}$.

constituent was calculated from the obtained results. It was found that, when $\mathrm{FeO}$ increased from 20 to $25 \%$, a range of $5 \%$, the conductivity increased 80 units. Also, when $\mathrm{CaO}$ increased from 30 to $35 \%$, a range of $5 \%$, the conductivity increased 300 units. On the other hand, when $\mathrm{SiO}_{2}$ increased from 15 to $20 \%$, a range of $5 \%$, the conductivity decreased 150 units. Although $\mathrm{FeO}$ has lowest melting point and the highest conductivity, Table 1, and also it undergos both ionic and electronic conductivity, the sensitivity of $\mathrm{CaO}$ and $\mathrm{SiO}_{2}$ is larger. Most likely this because the effect of $\mathrm{CaO}$ and $\mathrm{SiO}_{2}$ on existance of silicate netwerk and its great effect on viscosity. Average conductivity index per percent of each slag main constituent was calculated. It was calculated by dividing the total change in conductivity by the total change in concentration for each constituent. Conductivity index for $\mathrm{CaO}$ at $1600^{\circ} \mathrm{C}$ was estimated and found $+60 \mathrm{~S} / \mathrm{m}$ per each $1 \%$ increase in $\mathrm{CaO}$. Also, Conductivity index for $\mathrm{FeO}$ at $1600^{\circ} \mathrm{C}$ was estimated and found $+16 \mathrm{~S} / \mathrm{m}$ per each $1 \%$ increase in $\mathrm{FeO}$. On the other hand, Conductivity index for $\mathrm{SiO}_{2}$ at $1600^{\circ} \mathrm{C}$ was found $-30 \mathrm{~S} / \mathrm{m}$ per each $1 \%$ increase in $\mathrm{SiO}_{2}$.

\section{Conclusion and Recommendations}

The effect of Temperature, $\mathrm{FeO}, \mathrm{SiO}_{2}, \mathrm{CaO}$ and basicity of slag on its electrical conductivity was investigated. The following conclusions can be drawn:

- As the temperature increases, the slag electrical con- ductivity increases.

- As the $\mathrm{FeO}$ and/or $\mathrm{CaO}$ content increase, the slag electrical conductivity increases.

- As the $\mathrm{SiO}_{2}$ content increases, the slag electrical conductivity decreases.

- As the basicity B2 increases, the slag electrical conductivity increases.

Accordingly and to bring slag to the optimum electrical conductivity, it is recommended to keep the basicity higher than 2, it is level that guarantee the breaking of the entire silicate network. Also it is recommended to keep the $\mathrm{FeO}$ content at a level high enough but not to the limit of reaching the watery slag.

\section{Acknowledgment}

The authors are deeply grateful to EZZ FLAT STEEL Company for supporting this study and also to Eng. Ahmed Ali and his team for their help in facilities setting up.

\section{REFERENCES}

1) K. C. Mills, L. Yuan and R. T. Jones: J. South. Afr. Inst. Min. Metall., 111 (2011), 649

2) J. Jia, X. Liao, D. Li, C. Ni, G. Zhao and D. Cao: Proc. 9th Int. Conf. on Molten Slags, Fluxes and Salts, Tsinghu Knowledge Network Technology, Beijing, (2012), 64.

3) A. Sorek, P. P. Ostrowska and M. Niesler: Arch. Mater. Sci. Eng., 57 (2012), Issue 2, 53.

4) L. Mongalo, A. S. Lopis and G. A. Venter: J. Non-Cryst. Solids, 452 (2016), 194.

5) R. J. Hundermark, S. Jahanshahi and S. Sun: 22nd Int. Mineral Processing Cong., South African Institute of Mining \& Metallurgy, Marshalton, (2003), 1370.

6) K. C. Mills, L. Yuan, Z. Li, K. Chou and G. Zhang: Proc. 9th Int. Conf. on Molten Slags, Fluxes and Salts, Tsinghu Knowledge Network Technology, Beijing, (2012), 301.

7) Q. Jiao and N. J. Themelis: Metall. Trans. B, 19 (1988), 133.

8) Y. U. Han and D. J. Min: Advances in Molten Slags, Fluxes, and Salts: Proc. 10th Int. Conf. on Molten Slags, Fluxes and Salts (MOLTEN16), Wiley-TMS, Hoboken, NJ/Warrendale, PA, (2016), 501.

9) H. C. Chuang, W. S. Hwang and S. H. Liu: Mater. Trans., 50 (2009), No. 6,1448

10) L. Wang: Steel Res. Int., 80 (2009), 680.

11) Slag Atlas, 2nd ed., ed. by VDEh, Verlag Staheisen, Düsseldorf, (1995), 17.

12) W. Li, X. Cao, T. Jiang, H. Yang and X. Xue: ISIJ Int., 56 (2016), 205. 